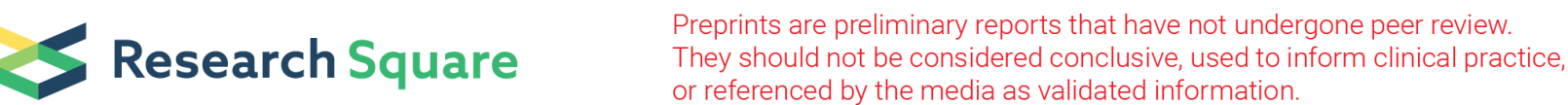

\section{Millennial-scale Land-surface Temperature and Soil Moisture Reconstruction Derived From Last Glacial European Loess Sequences}

Charlotte Prud'homme ( $\nabla$ charlotte.prudhomme@unil.ch )

University of Lausanne https://orcid.org/0000-0002-1417-033X

\section{Peter Fisher}

Johannes-Gutenberg-Universität Mainz

Olaf Jöris

MONREPOS Archaeological Research Centre and Museum for Human Behavioural Evolution

\section{Sergey gromov}

Max Planck Institute for Chemistry

Mathias Vinnepand

Johannes-Gutenberg-Universität Mainz

Christine Hatté

Université Paris-Saclay

Hubert Vonhof

Max Planck Institute for Chemistry https://orcid.org/0000-0002-0897-8244

\section{Olivier Moine}

Environnements Quaternaires et actuels, UMR 8591 CNRS Université Paris 1 UPEC

\section{Andreas Vött}

Johannes-Gutenberg-Universität Mainz

Kathryn Fitzsimmons

University of Tübingen

\section{Article}

Keywords:

Posted Date: February 2nd, 2022

DOI: https://doi.org/10.21203/rs.3.rs-1280228/v1

License: (c) (1) This work is licensed under a Creative Commons Attribution 4.0 International License.

Read Full License 
Version of Record: A version of this preprint was published at Communications Earth \& Environment on November 21st, 2022. See the published version at https://doi.org/10.1038/s43247-022-00595-3. 


\section{Abstract}

The climate of the last 50,000 years has been punctuated by oscillations on millennial-to-centennial timescales. Our understanding of this variability derives predominantly from proxy information in ice and marine cores; high-resolution records from land are scarce. Here we quantify land-surface temperature and soil moisture at millennial timescales over continental Europe, for the period spanning 45,000 to 22,000 years before present. We provide the first quantitative terrestrial counterpart to marine and ice-core derived reconstructions for the North Atlantic region. Our terrestrial reconstruction derives from novel isotopic geochemistry and radiocarbon dating of earthworm calcite granules, collected from two temporally overlapping loess palaeosol sequences in the Rhine Valley, Germany. We combine our proxy reconstructions with mesoscale wind and moisture transport modelling. We find that compared with polar and Mediterranean regions, climatic warming from stadial to interstadial phases is attenuated in centralwestern Europe. The region was dominated by westerly air masses during the last glacial maximum but experienced seasonal variability in wind steadiness. We observe a strong correlation between abrupt temperature variability recorded in the Greenland ice core and the periglacial environments further south. This correlation is likely due to air masses arriving to the Rhine valley are deriving from the North Atlantic.

\section{Introduction}

The climate of the northern hemisphere went through numerous, abrupt, short-lived variations over the last glacial period (112000 - 12000 years). In the terrestrial realm, these resulted in landscape and ecological change. Our understanding of millennial-scale climate variability is, however, better understood from ice core and marine records. In the northern hemisphere, these short-lived oscillations, are first described from Greenland ice cores ${ }^{1}$ and subsequently in marine cores from the North Atlantic ${ }^{2}$. Dansgaard-Oeschger cycles comprise mild Greenland Interstadials (GIs) defined by sudden warming over several decades followed by gradual cooling over several centuries, bundled with Greenland stadials (GSs), characterized by abrupt cooling and more stable cold climates ${ }^{1,3,4}$. Evidence for short-lived, particularly cold phases derives from coarse-grained layers of ice-rafted debris (IRD) preserved within North Atlantic marine sediment ${ }^{5}$ known as Heinrich events. Heinrich events are associated with a significant drop in sea-surface temperatures (SST ${ }^{6}$ and were coeval with the most prominent GSs. They typically occurred towards the end of sequences of Gls of decreasing amplitude (Bond-cycles) ${ }^{7}$. These short-term climate variations were likely triggered by sudden changes in the Atlantic Meridional Overturning Circulation (AMOC) and are associated with variability in North Atlantic Sea ice cover ${ }^{8}$. Over the last 45,000 years, twelve GIs (GI 1-12) and five Heinrich events $(\mathrm{HO}-\mathrm{H} 4)$ have been recorded in Greenland ice cores ${ }^{3}$ and marine sediments ${ }^{9}$, respectively.

Although similar millennial-scale climate variations are also recorded in European terrestrial archives such as lakes ${ }^{10-13}$, continental margins ${ }^{14,15}$, speleothems ${ }^{16-18}$ and tufa ${ }^{19}$, most are of limited spatial or temporal extent, and quantitative information about climate parameters such as temperature and rainfall are difficult to be provided. This limitation constrains our understanding of the relative influence 
of competing climate agents such as the AMOC or ice sheet extent on Earth-surface response to climatic changes ${ }^{20}$.

Here we generate quantitative terrestrial palaeoclimate data from proxy information stored within aeolian loess in western Europe. Compared with discontinuous local archives, loess deposits cover a larger geographic area, and experience higher sedimentation rates, while also preserving in situ proxy climatic information. The European loess spans much of the continent in a belt between ca. $45-55^{\circ} \mathrm{N}$ and represents the most extensive terrestrial archive of the last glacial period on the continent ${ }^{21-23}$. The relatively high accumulation rates in loess (up to $1 \mathrm{~mm} . \mathrm{yr}^{-1}$ during stadial periods) ensure high resolution, sensitive coverage of (sub-)millennial climatic cycles, which are recorded stratigraphically as stadial primary loess and intercalated interstadial palaeosols ${ }^{24-26}$. The physical properties of loess deposits depend on the intensity and duration of interstadial and stadial phases, vegetation cover and sedimentation rates ${ }^{26,27}$, and its palaeoclimatic context has mostly been qualitatively investigated by analysis of mollusc assemblages ${ }^{28-30}$, the isotopic signal of organic matter ${ }^{31,32}$, and biomarkers ${ }^{33-35}$. Recent studies have highlighted the potential for the reliable extraction of chronological and quantitative palaeoclimatic data from a bio-indicator: fossil earthworm calcite granules (ECGs), which are well preserved within European loess-palaeosol sequences ${ }^{36-39}$. These granules are secreted daily at the soil surface ${ }^{40}$ by various earthworm species - Lumbricus terrestris being the most productive ${ }^{41}$ - experience limited mixing within soil horizons ${ }^{42}$, and comprise rhombohedral low-Mg calcite crystals which are resistant to diagenetic alteration ${ }^{43}$. The oxygen and carbon isotopic compositions of ECGs can be used as direct proxies for land-surface temperature ${ }^{44}$ and soil moisture ${ }^{45}$, and ECGs provide reliable radiocarbon chronology at a temporal resolution much higher than other dating methods commonly used in loess-palaeosol sequences ${ }^{25,26}$.

We extracted a new quantitative climate dataset from the joint stable isotope composition and radiocarbon dating of ECGs at high temporal resolution for the time period 45,000- and 22,000-years cal BP (45-22 cal kBP), from two temporally overlapping loess sequences, namely Schwalbenberg ${ }^{26,46}$ and Nussloch ${ }^{24,25}$, situated in the Rhine River valley of western Germany (Fig. 1). We embed our climate reconstructions within Bayesian age models for both loess-palaeosol sequences, facilitating precise correlation between the two sequences, and with other climatic archives for the North Atlantic region. We link our results with wind and precipitation modelling at the macro scale in order to more meaningfully understand potential teleconnections between continental Europe, the Fennoscandian ice sheet and North-Atlantic Ocean.

\section{Results}

\section{Stratigraphy}

This study investigated fossil ECGs extracted from two loess-palaeosol sequences (Schwalbenberg and Nussloch), which are located c. $180 \mathrm{~km}$ from one another along a north-south transect in the non- 
glaciated zone between the Last Glacial Maximum (LGM) extents of the Alpine and Fennoscandian ice sheets (Fig. 1). The Schwalbenberg profile (RP1) is located on the left bank of the Rhine River in the Middle Rhine valley, at the confluence of the Rhine and Ahr rivers near the city of Remagen ${ }^{26,46}$ (Fig. 1). Upper Pleistocene loess-palaeosol sequences at this site reach $30 \mathrm{~m}$ in thickness and form a gently south-eastward sloping plateau ${ }^{26}$. Aeolian sediments most likely derive from adjacent river systems and the periglacial low mountain range of the Rheinish Massif. High dust accumulation rates occur in leeward position of a ridge formed by palaeozoic bedrock west of the Schwalbenberg associated to overall (south-)westerly wind regimes. The 6-m-thick Schwalbenberg RP1 section lies on the southeastern flank of the plateau and archives environmental change during late MIS 3 and MIS 2, including pedocomplex (Calcaric Cambisols) development during MIS 3 and a cyclic succession of loess and tundra gley horizons during MIS $2^{26,46}$.

Nussloch is situated on the eastern margin of the Upper Rhine valley (Fig. 1). The sediments are assumed to derive from local deflation of the Rhine alluvial plain to the west, accumulating at the junction between the Kraichgau and Odenwald uplands in northwest - southeast (NNW-SSE) oriented elongate ridges named "gredas" 24 . This combination of topographic context and strong northwesterly wind regimes during the last glacial period ${ }^{24}$ facilitated high dust accumulation rates at Nussloch during this time. The Nussloch P8 profile is $17 \mathrm{~m}$ thick. The lower $5 \mathrm{~m}$ dated to MIS 3 comprise the development of arctic and boreal brown soils alternating with primary loess and tundra gley horizons and the upper $12 \mathrm{~m}$ corresponding to MIS 2 comprise alternating primary loess and tundra gley layers ${ }^{24}$.

Both Remagen and Nussloch preserve evidence of periglacial and permafrost activity to varying degrees. Tundra gley horizons are present in both sites and reflect short-term phases of formation then degradation of former active permafrost layers. During MIS 3, calcaric cambisols developed in the surficial sediments at Schwalbenberg, whereas tundra gleys are observed for the same time period at Nussloch. These pedostratigraphic differences between the sites suggest that permafrost features were significantly weaker at Schwalbenberg compared to Nussloch, possibly due to its more sheltered situation and southerly aspect.

\section{Age models and temporal resolution}

The chronologies for sediment accumulation at both Schwalbenberg (RP1, Fig. 2) and Nussloch (P8, Fig. 3) profiles were determined using radiocarbon dating of ECGs. We derived Bayesian age models for each profile using Bacon software ${ }^{47}$ (see Methods) (Fig. 4, Supplementary Table 2 and 3).

Our age model for Remagen RP1 is based on 22 dates and spans 39,963-38,162 and 22,150-21,426 cal BP (Fig. 2, Supplementary Table 1). A visible unconformity observed within the section (unit 13) is modelled as a 5-ka hiatus spanning from 30,970-30,199 to 24,619-23,863 cal BP. We calculated accumulation rates of the order of $\sim 0.5-0.6 \mathrm{~mm}_{\mathrm{yr}} \mathrm{y}^{-1}$ for MIS 3, reaching a peak of $2.0 \mathrm{~mm} . \mathrm{yr}^{-1}$ between 23-22 cal kBP before reducing to $0.56 \mathrm{~mm} \cdot \mathrm{yr}^{-1}$ thereafter. 
Radiocarbon ages on ECGs have previously been published for the Nussloch P8 profile 24 ; here we undertake Bayesian age-depth modelling and calculation of sedimentation rates based on those data ${ }^{25}$. Calibrated dates range from 47,862-45,354 to 22,752-21,577 cal BP, preceding Schwalbenberg RP1 by c. 7 kyr and temporally overlapping with it (Fig. 3, Supplementary Table 1). Sedimentation rates between 43 and 32 cal kBP are comparable with Schwalbenberg profile RP1 ( 0.5 to $\left.0.6 \mathrm{~mm} . \mathrm{yr}^{-1}\right)$. Short-lived peaks (up to $1 \mathrm{~mm} \mathrm{yr}^{-1}$ ) in dust accumulation during MIS 2 were constrained to c. 30, 25.5 and $24 \mathrm{cal} \mathrm{kBP}$, and appear to be contemporaneous with increased dust inputs to the Greenland ice core ${ }^{3}$ (Fig. 5).

\section{Stable isotope composition}

We measured the carbon and oxygen isotope values of ECGs for 23 layers of $5 \mathrm{~cm}$-thick from profile RP1 at Schwalbenberg, for a total of 690 analyses (Fig. 4, supplementary Fig. 1 and supplementary Table 2). The Nussloch record incorporates an already published stable isotope dataset (11 layer of $5 \mathrm{~cm}$-thick representing 330 analyses) ${ }^{44,45}$ with an additional 210 new analyses from 7 layers (Fig. 4, Supplementary Fig. 2 and Supplementary Table 3).

At Schwalbenberg, the ECGs extracted from the interstadial phases ( 270 analyses) yielded mean values of $-12.5 \pm 1.0 \%$ o for $\delta^{13} \mathrm{C}$ and $-4.5 \pm 1.8 \%$ o for $\delta^{18} \mathrm{O}$. Results for samples from stadial phases (420 analyses) yielded mean $\delta^{13} \mathrm{C}$ and $\delta^{18} \mathrm{O}$ values of $-12.2 \pm 1.0 \%$ ond $-4.8 \pm 1.8 \%$ o respectively. The stable isotope compositions of both carbon and oxygen in ECGs are statistically distinguishable between the stadial and interstadial phases ( $\mathrm{p}$-value $=8.9 * 10^{-6}$ and 0.04 , respectively).

The mean carbon isotopic composition values for ECGs from Nussloch are - $12.4 \pm 0.9 \%$ o for interstadials (420 analyses) and $-11.7 \pm 0.9 \%$ for stadial phases (120 analyses). Mean oxygen values of ECGs during interstadials and stadials are $-5.2 \pm 1.9 \%$ ond $-6.3 \pm 1.7 \%$ o respectively. The mean values of carbon and oxygen isotope values during stadials and interstadials are statistically different based on T-test $p$-value results of $2.3^{*} 10^{-8}$ and $1.6 * 10^{-15}$ respectively).

\section{Quantitative reconstruction of terrestrial climate parameters}

The stable carbon and oxygen isotope compositions measured from ECGs can be used as direct proxies for annual soil moisture ${ }^{45}$ and warm-season land-surface temperature ${ }^{44}$.

Since the main source of carbon in ECGs derives from a mixture of litter and soil organic matter ${ }^{48}$, the $\delta^{13} \mathrm{C}$ values of plants can be estimated by accounting for the fractionation factor $(-11.7 \pm 1.5 \%$ o $)$ that results from the difference between the carbon ingested by the earthworms and that which is integrated into the ECGs ${ }^{48}$. Following calculation of the $\delta^{13} \mathrm{C}$ values of plants, we used a published empirical equation ${ }^{49,50}$ based on the linear relationship between plant leaf discrimination $\left(\Delta^{13} \mathrm{C}_{\text {plants }}\right)$ and precipitation to reconstruct annual soil moisture. The $\Delta^{13} \mathrm{C}_{\text {plants }}$ is dependant of $\delta^{13} \mathrm{C}$ of plants calculated from the $\delta^{13} \mathrm{C}$ of ECG and of $\delta^{13} \mathrm{C}$ values of atmospheric $\mathrm{CO}_{2}\left(\delta^{13} \mathrm{C}_{\mathrm{atm}}\right)$ which were estimated from air bubbles trapped within the Vostok ice core between 50 and $20 \mathrm{ka}^{51}$. 
The oxygen isotope composition of the ECGs is related both to soil temperature and the isotopic composition of soil pore water ${ }^{52}$. Based on the empirical equation using observations of modern earthworm response to temperature ${ }^{52}$, the $\delta^{18} 0$ value of soil water need to be estimated to quantify the temperature. The $\delta^{18} \mathrm{O}$ value of soil water reflects the $\delta^{18} \mathrm{O}$ of meteoric water $\left(\delta^{18} \mathrm{O}_{\mathrm{mw}}\right)^{53}$, which is itself linearly dependent on mean air temperature at mid- to high latitudes ${ }^{54,55}$. We used a linear equation relating the $\delta^{18} \mathrm{O}_{\mathrm{mw}}$ to the mean annual air temperature $\left(\mathrm{T}_{\mathrm{a}}\right)$ by compiling International Atomic Energy Agency (IAEA) modern rainfall data from the 72 available mid- to high-latitude stations located across North America and Europe ${ }^{44}$.

$$
\delta^{18} O_{m w}=[0.72 \pm 0.03] \mathrm{Ta}-[15.97 \pm 0.28]
$$

The period of interest to this study (MIS 3-2) oversaw substantial changes in hemispheric ice volume and consequently the oxygen isotope ratios of both sea and meteoric water, which needed to be accounted for in our calculations. During MIS 3 and MIS 2, sea levels varied from 60 to $120 \mathrm{~m}$ below the modern sea level respectively ${ }^{56}$ and contributed to a major reshaping of northwest European palaeogeography, with both the southern North Sea and English Channel connected to the continent by land (Fig. 1) ${ }^{57}$. Glacioeustatic sea-level fluctuations reflect changes in the continental ice volume budget and can therefore be used to estimate past global $\delta^{18} O$ values in seawater. During MIS 2, the $\delta^{18} O$ of seawater was $1.0 \pm$ $0.1 \%{ }^{58}$. During MIS 3 we assumed that the $\delta^{18} \mathrm{O}$ of seawater was intermediate between that of MIS 2 and of the Holocene $(0 \% \text {; SMOW reference })^{56,59}$; we took MIS 3 values to be $0.5 \%$ o. Consequently, by estimating the $\delta^{18} \mathrm{O}$ of meteoric water and taking into account the ice volume effect, we calculated warmseason land-surface temperatures, as oxygen stable isotope compositions record soil temperatures during the seasonal activity of the earthworms, which probably occurred during the active-layer thawing season (May to September, the five warmest months of the year; data from Global Terrestrial Network for Permafrost http://gtnpdatabase.org). Air temperatures were assumed to be $\sim 3^{\circ} \mathrm{C}$ colder than soil temperatures as is typical for present-day periglacial environments ${ }^{60,61}$. We therefore propose that the oxygen isotope composition of ECGs records land-surface temperatures for the warmest period of the year (LSTws) rather than mean annual land-surface temperature (LST).

At Schwalbenberg, warm season land-surface temperatures ranged from $10.3 \pm 4.3^{\circ} \mathrm{C}$ to $14.4 \pm 3.0^{\circ} \mathrm{C}$, and the mean annual soil moisture ranged from $215 \pm 107$ to $518 \pm 96 \mathrm{~mm} \cdot \mathrm{yr}^{-1}$ (Table 1). Nussloch yielded cooler temperatures $\left(7.5 \pm 3.8\right.$ to $13.7 \pm 5^{\circ} \mathrm{C}$ ) but comparable annual soil moisture (from $224 \pm 99$ to 490 $\pm 170 \mathrm{~mm} \cdot \mathrm{yr}^{-1}$ ) (Table 1). These estimates are $2-10^{\circ} \mathrm{C}$ cooler and somewhat drier than typical modern values $\left(\sim 15-16^{\circ} \mathrm{C}\right.$ and $\left.776-1030 \mathrm{~mm} . \mathrm{yr}^{-1}\right)$ for this region ${ }^{62}$. The coldest summer phases at each site were recorded during the GS 3 (between 25 and 26 ka BP), which was coeval with the Heinrich stadial H2. The warmest summer phases were during GI 7 ( 35 ka BP) at Schwalbenberg and GI 12 ( 45.5 ka BP) at Nussloch; the latter was eroded in the profile RP1 at Schwalbenberg. At Schwalbenberg the driest conditions prevailed during the LGM at $\sim 22 \mathrm{ka}$ BP, whereas at Nussloch the driest conditions were coeval with the coldest phase (Henrich stadial 2). The wettest conditions prevailed during the transition from GI 
6 to GS 6 ( 33 ka BP), and during GI 5.2 (32 ka BP), at Schwalbenberg and Nussloch respectively. Apparent discrepancies in the timing of extreme values between the sites reflects the lack of temporally overlapping data for the respective phases. Nussloch does not preserve sediments postdating $23 \mathrm{cal} \mathrm{kBP}$, and the period between $\mathrm{GI} 5.1$ and GI 2.2 is not preserved at Schwalbenberg profile RP1.

\section{Modelling wind and precipitation regime}

Our analysis of wind regimes and precipitation statistics at Nussloch and Schwalbenberg during the present day (1989-2018) and the LGM (21 ka) (Fig. 6 and supplementary Fig. 3 and 4) suggest that both sites preserve spatial differences in atmospheric general circulation and dust transport patterns. Today, south-westerlies prevail at Nussloch throughout the year, with lowest wind intensities in the summer. During the LGM, we identified dominant north-west and south winds, with the steadiest winds in summer, which contrast with steady winter winds in the present-day. We observed generally more unstable, stronger winds at Schwalbenberg in the present day, favouring a south-west direction with higher speeds in autumn and winter. The LGM reconstructions provide a contrast, whereby only summer west/northwest winds are comparable in intensity and steadiness, whereas easterlies were more pronounced in other seasons (Fig. 6 and supplementary Fig. 3 and 4). Generally, south-westerlies bring most of the precipitation to Schwalbenberg during the LGM. We interpret larger wind direction changes at Nussloch which would have disfavoured preferable wind directions for precipitation.

Model-based reconstructions of past atmospheric transport pathways and their relationship to loess deposition rates in the Rhine Valley could provide substantial insights into atmospheric circulation patterns over the timescales of climate oscillations investigated here. As yet, however, there are no models on mesoscale or even general atmospheric circulation for MIS 3 or the millennia prior to the LGM.

\section{Discussion}

Previous studies have demonstrated that the Schwalbenberg 26,63 and Nussloch $24,25,64$ sequences preserve stadial-interstadial climate variability at high temporal resolution. Our new age modelling and geochemical data, combined with wind regime modelling for the present day and LGM time slices, provide the first opportunity to meaningfully examine terrestrial climate change over millennial timescales for comparison with other North Atlantic region archives.

The integration of sedimentation rate calculations (based on age modelling) and wind regime reconstruction suggests that the two sites provide contrasting information relating to atmospheric circulation. At Nussloch, dust accumulated almost continuously from 50 to $20 \mathrm{cal}$ kBP and experienced peaks during Heinrich stadials 3 and 2. The timing of peak dust fluxes was coeval with dust peaks in the Greenland ice core and suggest periods of stronger winds and drier conditions at Nussloch, likely to indicate phases of significant transitions in northern hemispheric wind regimes (Fig. 5). By contrast, at Schwalbenberg, local topography appears to play a larger role. Loess deposited at Schwalbenberg is assumed to derive mostly from local source areas. Sediments from the Ahr River immediately to the south and from the low mountain range are transported by westerly and south-westerly winds, whereas 
local wind gusts are likely to have transported sediment from the Rhine River immediately east. The likely dominance of localized wind gusts, combined with evidence of erosion in the upper part of the Schwalbenberg RP1 sequence $26,46,65$, indicates that these deposits are dominated by reworked loess for which accumulation rates are unlikely to have meaning beyond the local context. We therefore refrain from comparing sedimentation rates between the two sites for this time interval.

Our quantitative climatic reconstructions are derived from in situ ECG response to contemporary conditions at the land surface and are therefore independent of sedimentation rates or direct wind transport vectors. As such, they provide insights into terrestrial climate parameters at sufficiently high resolution for comparison with other archives from western Europe and the North Atlantic region. Whilst past environmental changes for Schwalbenberg and Nussloch have previously been reconstructed from malacological analysis ${ }^{30,66}$, ECG concentration ${ }^{38}$ and palaeoprecipitation estimates derived from inverse modelling of $\delta^{13} \mathrm{C}$ of organic matter ${ }^{31,67}$, as yet none of these datasets have been of sufficient resolution to facilitate meaningful correlations of the temporal and geographic scale attempted here (Table 1, Fig. 5). We are aware that uncertainties associated with our quantitative estimates of climate parameters are sizeable, however it is important to note that earthworms produce calcite granules daily while active, and therefore each ECG records a snapshot of past land-surface temperatures and soil moistures during the earthworm activity season. Our estimates are nevertheless in agreement with other (lower resolution) quantitative estimates for past climate parameters in terrestrial Europe based on palaeoecological transfer functions ${ }^{11,68-71}$, stable isotope composition of loess carbonates ${ }^{44,72}$ and inverse modeling based on the $\delta^{13} \mathrm{C}$ of soil organic matter ${ }^{31,67,73}$.

We find that the warmest months of stadial phases in the Rhine Valley were on average $1-4^{\circ} \mathrm{C}$ cooler than for interstadials (Table 1, Fig. 5). The more northern site of Schwalbenberg yields higher warm season temperatures than Nussloch throughout, which may be attributed to local influences such as the southfacing aspect. Overall, MIS 2 was c. $2.5^{\circ} \mathrm{C}$ cooler than MIS 3 at both sites and is interpreted to relate to reduced insolation during the glacial maximum (Fig. 5). Cold conditions prevailed during Henrich stadials 3 and 2 , with the intervening period coinciding with $\mathrm{GI} 3$ recording warmer temperatures $\left(\sim+4^{\circ} \mathrm{C}\right)$ at Nussloch, a phase which was characterized by abrupt warming in the Greenland region ${ }^{74}$. Overall, we observe comparable trends between our loess records and sea-surface temperatures recorded at the Iberian margin ${ }^{6}$ and isotopic proxies from the Greenland ice cores (Fig. 5), confirming that the Nussloch and Schwalbenberg archives from western/central Europe were directly influenced by changes in the North Atlantic climate system over the period studied. The trends observed in our palaeotemperature dataset correlate with other sufficiently high-resolution European loess records from eastern Hungary ${ }^{75}$ and northern England ${ }^{76}$. We observe that terrestrial response to millennial scale climate oscillations was both rapid and synchronous, albeit not as extreme as in the polar and Mediterranean Sea regions to the north and south respectively. We suggest that the milder climatic fluctuations observed in the terrestrial mid-latitudes was driven at multiple scales by insolation and local topography of the Rhine Valley. A reduction in insolation from MIS 3 to MIS 2 would have caused a decrease in mean annual temperature, however at local scales direct insolation may have led to relatively high summer temperatures, even 
during cold periods. Thus, while MIS 2 winters may have been significantly colder than during MIS 3 , the summers may have been almost as warm. Our land-surface temperatures for the period 45 to $23 \mathrm{cal} \mathrm{kBP}$ suggest that the highest temperatures were a function of insolation rather than other weather factors.

The concentration of ECGs and molluscs down-profile has previously been used as qualitative palaeoenvironmental proxies reflecting seasonal conditions, including biological activity and vegetation cover $^{30,38}$, which add nuance to our temperature dataset. At Nussloch, high concentrations of mollusc shells were observed during MIS 2 interstadials in combination with high juvenile mortality rates, suggesting increasing summer temperatures with abrupt temperature decreases during the transitions into the winter season reflected in earlier spring breeding and additional egg-laying phases in autumn ${ }^{30,77}$. This interpretation is comparable with pollen seasonal reconstructions from Les Echets in eastern France ${ }^{78}$ and with our suggestion that warmer active month temperatures, as reconstructed by our ECG proxy, may be decoupled from the mean annual temperatures dictated by net annual insolation.

We observe similar mean annual soil moisture values and variability throughout the last glacial period at both Schwalbenberg and Nussloch. Stadial phases are drier than the interstadials, the LGM being the driest (and coldest) period measured. In comparison, late MIS 3 was characterized by wetter conditions. Observations of palaeosol development indicate increased vegetation density at both sites at this time and agree with vegetation changes indicated by the Nussloch mollusc fauna ${ }^{66}$ as well as palaeoecological reconstruction from the nearby the Eifel Maar lakes ${ }^{10}$ and Bergsee ${ }^{13}$. Increasing precipitation across the continent may have contributed to the accelerated expansion of the Fennoscandian Ice Sheet from 38 ka onward and of the British Island Ice Sheet from $32 \mathrm{ka}^{79,80}$. Peak soil humidity in the Rhine valley is recorded between 33 and 32 cal kBP (GI 6 and GI 5.2) and is coeval with the expansion of the British Island Ice Sheet ${ }^{79}$ (Fig. 5). Subsequent to the peak in soil moisture at c. $32-$ 31 , stepwise drying is then recorded at Nussloch over the millennia from 31 to 23 cal kBP and correlates with both a weakening of the AMOC and associated rapid growth of the Fennoscandian Ice Sheet ${ }^{79-81}$. The isotope composition of organic carbon along with the litho- and pedostratigraphy of the key loess palaeosol sequence REM3 at Schwalbenberg ${ }^{26,63}$ also suggested an aridification with the development of thick loess deposits reaching up to $8 \mathrm{~m}$ (SSU E), unfortunately, this unit is strongly eroded in the Schwalbenberg profile RP1. Simultaneously, the Laurentide Ice Sheet reached its maximum extent over North America during Henrich stadial 2 (GS3, from 27 to $23 \mathrm{ka} \mathrm{BP}$ ). This resulted in a southward shift of the jet stream over southern Europe ${ }^{82,83}$ immediately preceding the LGM, suggesting a weakening of the North Atlantic Oscillation (NAO) ${ }^{84}$ and may have been one trigger for the pre-LGM aridification and cooling in the Rhine Valley.

Our combined geochemical and climate modelling results indicate that not only westerly but also southwesterly and northwesterly winds were responsible for moisture transported to the Rhine valley before and during the LGM, and that the steadiness of the dominant winds varied between the seasons. Our wind and precipitation reconstructions for the present day and LGM time slices primarily reflect changes to the general circulation pattern: the hemispheric extent of the extratropical jet, and typical 
location and intensity of (anti)cyclonic systems. We assume that the general circulation pattern is important for identifying dust and atmospheric moisture transport pathways (Fig. 6 and Supplementary Fig. 3 and 4). During the LGM, the main source of moisture to the Rhine Valley derived from the westerlies (SW and NW), which may have been weakened during phases of ice sheet volume expansion and associated westward expansion of the Siberian High. Cooler and drier conditions during such episodes (GS) are also likely to have affected seasonality by shortening warm seasons (Fig. 5 and 6 and Supplementary Fig. 3 and 4). This is coherent with reconstructions of moisture sources in the Alps interpreted from decreasing $\delta^{18} \mathrm{O}$ in a speleothem from the Sieben Hengste Cave $(7 \mathrm{H})^{16}$ (Fig. 5).

To conclude, this study generates the first millennial-scale quantitative terrestrial climate reconstruction for north-western Europe. We see our approach as a first step towards setting up spatially wide distributed data on land-surface temperatures based on ECG derived from loess-palaeosol sequences. Our air circulation models for the present-day and LGM time slices help us contextualise the impact of extreme climate phases on terrestrial environments. Quantitative climate parameters for the terrestrial realm have not been available for most of the Ice Age, preventing meaningful data-based comparison for system modelling of past changes in the global climate dynamics. Our dataset hints at significant correlation between changes in ice sheet cover and extent of periglacial aeolian environments (such the Rhine Valley deposits) across the North Atlantic region during much of the last glacial period. Although the correlation between temperature and soil moisture of the Rhine Valley loess with higher latitude ice sheet dynamics and North Atlantic sea-surface temperatures suggests a passive, and more moderate, response of the former to hemispheric climate drivers, such environments provide a timely illustration of what can occur during abrupt climatic transitions. The beginning of $\mathrm{Gl}$ periods provides useful analogues for current global warming conditions, whereby the thawing of permafrost released greenhouse gases and soil moisture, so prompting positive feedbacks to abrupt warming.

\section{Methods}

\section{Sampling strategy}

Continuous columns of samples were taken throughout the 5.5-m-thick Schwalbenberg profile RP1 at Remagen and throughout the 17-m-thick profile P8 at Nussloch. Schwalbenberg RP1 is located immediately at the northern edge of a former archaeological excavation site ${ }^{26,85}$. Nussloch P8 is situated about $50 \mathrm{~m}$ southeast of the reference profile $\mathrm{P}^{24}$. Before sampling, we refreshed and cleaned both sections by removing vertically about $50 \mathrm{~cm}$ of sediments. ECG were sampled at 5 -cm resolution by collecting $10 \mathrm{I}$ of sediments. After wet sieving at $0.5 \mathrm{~mm}$, ECG with a diameter larger than $0.8 \mathrm{~mm}$ were extracted under a binocular microscope. For stable isotope analyses, we selected 23 samples through the profile RP1 at Schwalbenberg (Supplementary Fig. 1). For Nussloch profile P8, we analysed 7 new samples (each $5-\mathrm{cm}$ thick) that we added to the 11 previously published ${ }^{44,45}$ for this profile (Supplementary Fig. 2). ECGs were selected from tundra gley units, brown soils and loess horizons.

\section{Radiocarbon dating}


Sample preparation and radiocarbon analysis protocol followed the procedure as described by ref. ${ }^{25}$. After cleaning the ECG by ultrasonic bath, $100 \mu \mathrm{g}$ (gas source) or $1000 \mu \mathrm{g}$ (solid source) per dating sample were crushed in an agate mortar. All samples were then leached with $0.01 \mathrm{M} \mathrm{HNO}_{3}$ at room temperature for 30 minutes and rinsed with Milli-Q water to remove superficial contamination and to oxidize any remaining organic matter. Samples are then introduced into the bottom of a two-fingers reactor and $1 \mathrm{~cm}^{3}$ of pure $\mathrm{H}_{3} \mathrm{PO}_{4}$ is added into the lateral reservoir. The reactor with the wet sample and $\mathrm{H}_{3} \mathrm{PO}_{4}$ is then connected to the semi-automated vacuum line ${ }^{86}$. The sample is finally dried on the line, and the reactor is manually rotated to pour $\mathrm{H}_{3} \mathrm{PO}_{4}$ onto the samples. Subsequent steps (reduction for solid source and physical measurement) are either performed by the Laboratoire de Mesure du Carbone 14 , Saclay ${ }^{87}$ (LMC14, lab code SacA) on a traditional large AMS or by the ${ }^{14} \mathrm{C}$ research group of the LSCE, Gif-sur-Yvette (lab codes GifA for chemistry and ECHo for physical measurement) on both solid and gas source of the ECHoMICADAS ${ }^{88-90}$. To control the impact of chemical treatment and of the combustion, "blank" and international standards were run. Results are expressed in $\mathrm{F}^{14} \mathrm{C}$ as recommended by Reimer et al. $2004^{91}$ and provided as ${ }^{14} \mathrm{C}$ ages (BP) following Stuiver and Polach (1977) ${ }^{92}$ convention (Supplementary table 1). Calibrated ages are reported following Millard's (2014) ${ }^{93}$ recommendations. Replicates and triplicates from six layers in RP1 have been performed to check the reliability between the two methods, the gas source using 10 times less materials (Supplementary table 1).

\section{Age-depth models and sedimentation rates}

The chronology of Schwalbenberg and Nussloch was determined using radiocarbon analyses on ECG (Figs. 2 and 3 and Supplementary Table 1). We derived age-depth models using the software BACON $2.2^{47}$ based on Bayesian statistics. For Nussloch, we selected the radiocarbon ages ( 29 samples) of the profile P8 as age control points prior to running the Bayesian age model. For Schwalbenberg, the model is based on 23 age control points. On average, at Schwalbenberg, the resolution of one radiocarbon sample is every $\sim 20 \mathrm{~cm}$ whereas in Nussloch the resolution is every $\sim 60 \mathrm{~cm}$. Probability distributions of calibrated radiocarbon ages were generated using IntCal2 $0^{94}$ in the Bacon code $c c=1$. In Bacon program ${ }^{47}$, two prior distributions (gamma distribution for the accumulation rate and beta distribution for the accumulation memory) are constrained. We used the default values: accumulation (acc). shape=1.5 for the gamma distribution; memory(mem.)mean=0.7 and mem.strength $=4$ for the beta distribution. The mean accumulation rate was change to $50{\mathrm{yr} . \mathrm{cm}^{-1}}^{-1}$ according to information available from calibrated ${ }^{14} \mathrm{C}$ dates and we run our sequences with 50 and 135 sections respectively for Schwalbenberg and for Nussloch. We choose a resolution of $5 \mathrm{~cm}$ for the age-modelling to obtain an individual age for each stable isotope sample. The sedimentation rates for both profiles were calculated based on age modelling output at $5 \mathrm{~cm}$ resolution.

\section{Stable isotope analysis of earthworm calcite granules}

We followed the procedure for the extraction of the ECGs and the preparation protocol from ref. ${ }^{44,45}$. After cleaning in an ultrasonic bath with deionized water (2 times 5 minutes), thirty ECGs were extracted 
from each sample for stable isotope analysis based on the absence of impurities and the well-preserved surface crystals. We performed 240 and 690 stable isotope analyses for Nussloch and Schwalbenberg, respectively. Individual granules were crushed, and an aliquot between 200-300 $\mu \mathrm{m}$ of carbonate powder was digested with phosphoric acid at $70^{\circ} \mathrm{C}$ in an exetainer vial and flushed with helium gas. The liberated $\mathrm{CO}_{2}$ was analysed using a Thermo Finnigan GasBench II preparation device interfaced with a Thermo Delta $V$ advantage mass spectrometer at the Max Plank Institute of Chemistry in Mainz. All $\delta^{13} \mathrm{C}$ and $\delta^{18} \mathrm{O}$ values are reported relative to the Vienna-Peedee Belemnite (V-PDB) standard. The long-term standard deviation of a routinely analysed in-house $\mathrm{CaCO}_{3}$ standard was $<0.1 \%$ o $(1 \sigma)$ for both carbon and oxygen isotope ratios. The $\mathrm{CaCO}_{3}$ standards are calibrated using NBS19, NBS18 and IAEA 603. Mean and standards deviations values of each layer are compiled in Supplementary Tables 2 and 3.

\section{Wind dynamics model reconstructions}

Wind and precipitation statistics are derived from the instantaneous values of 10-metre winds and total precipitation sampled at 6-hourly (synoptic) intervals from continuous 30 years output of the respective atmospheric general circulation model products. For the present-day conditions, we use the output of the ERA INTERIM reanalysis ${ }^{62}$ at $1^{\circ}$ by $1^{\circ}$ horizontal resolution covering the $1989-2018$ period. Note that reanalysis precipitation data are based on forecasted fields. For the LGM conditions, we use the output of the MPIESMP model (simulation r1i1p1P, approx. $1.88^{\circ}$ horizontal resolution) participated in the Climate Model Intercomparison Project, Phase 5 (CMIP5). MPIESMP combines the coupled general circulation models for the atmosphere ECHAM6 and ocean MPIOM and the land surface model JSBACH with vegetation cover prescribed to pre-industrial reconstructions ${ }^{95}$. LGM climate simulated in MPI-ESM-P compared well with to date available proxy data ${ }^{96}$. Values are sampled in respective model grid cells without interpolation.

\section{Declarations}

\section{Acknowledgements}

This work was supported by the German Science Foundation (Deutsche Forschungsgemeinschaft, DFG) in the framework of the TerraClime-Project (FI 1941/5-1; FI 1918/4-1; VO 938/25-1) awarded to PF, KEF and AV, and by an independent Max Planck Research Group awarded to KEF. SG acknowledges support through the project PalMod, funded by the German Federal Ministry of Education and Research (BMBF).

We thank Sven Brömme for help in the stable isotope laboratory and Felix Hettwer for helping to extract the earthworm calcite granules. We thank everyone who assisted with fieldwork in Remagen, including Stefania Milano and Kristina Reetz.

\section{Author contributions}

$\mathrm{CP}, \mathrm{KEF}$ and PF designed the study and $\mathrm{CP}, \mathrm{PF}, \mathrm{OJ}, \mathrm{MV}$ and $\mathrm{OM}$ conducted the fieldwork. 
$\mathrm{CP}$ and $\mathrm{HV}$ conducted the stable isotope analyses

$\mathrm{CP}$ prepared the samples prior radiocarbon dating and $\mathrm{CH}$ performed the analyses

SG performed the analysis of wind and precipitation regime reconstructions.

All authors contributed to discussion, interpretation of the results and writing of the manuscript.

\section{Competing interests}

The author(s) declare no competing interest

\section{Data availability}

All data generated or analysed during this study are included in this published article (and its Supplementary Information files).

\section{References}

1. Dansgaard, W. et al. Evidence for general instability of past climate from a $250-k y r$ ice-core record. Nature 364, 218-220 (1993).

2. Bond, G. et al. Correlations beween climate records from North Atlantic sediments and Greenland ice. Nature Letters 363, 143-147 (1993).

3. Rasmussen, S. O. et al. A stratigraphic framework for abrupt climatic changes during the Last Glacial period based on three synchronized Greenland ice-core records: Refining and extending the INTIMATE event stratigraphy. Quaternary Science Reviews 106, 14-28 (2014).

4. NGRIP members. High-resolution record of Northern Hemisphere climate extending into the last interglacial period. Nature 431, 147-151 (2004).

5. Heinrich, $\mathrm{H}$. Origin and Consequences of Cyclic Ice Rafting in the Northeast Atlantic Ocean during the Past 130,000 Years. Quaternary Research 29, 142-152 (1988).

6. Martrat, B. et al. Four Climate Cycles of Recurring Deep and Surface Water Destabilizations on the Iberian Margin. Science 317, 502-507 (2007).

7. Broecker, W. S. Massive iceberg discharges as triggers for global climate change. Nature vol. 372 421-424 (1994).

8. Menviel, L. C., Skinner, L. C., Tarasov, L. \& Tzedakis, P. C. An ice-climate oscillatory framework for Dansgaard-Oeschger cycles. Nature Reviews Earth \& Environment 1, 677-693 (2020).

9. Hemming, S. R. Heinrich events: Massive late Pleistocene ditritus layers of the North Atlanitc and their global cliamate imprint. Reviews of Geophysics 42, 1-43 (2004).

10. Sirocko, F. et al. The ELSA-Vegetation-Stack: Reconstruction of Landscape Evolution Zones (LEZ) from laminated Eifel maar sediments of the last 60,000years. Global and Planetary Change 142, 108-135 (2015). 
11. Bohncke, S. J. P., Bos, J. A. A., Engels, S., Heiri, O. \& Kasse, C. Rapid climatic events as recorded in Middle Weichselian thermokarst lake sediments. Quaternary Science Reviews 27, 162-174 (2008).

12. Sirocko, F. et al. Muted multidecadal climate variability in central Europe during cold stadial periods. Nature Geoscience 14, 651-658 (2021).

13. Duprat-Oualid, F. et al. Vegetation response to abrupt climate changes in Western Europe from 45 to $14.7 \mathrm{k}$ cal a BP: the Bergsee lacustrine record (Black Forest, Germany). Journal of Quaternary Science 32, 1008-1021 (2017).

14. Sánchez-Goñi, M. F. et al. Contrasting impacts of Dansgaard-Oeschger events over a western European latitudinal transect modulated by orbital parameters. Quaternary Science Reviews 27, 1136-1151 (2008).

15. Fletcher, W. J. et al. Millennial-scale variability during the last glacial in vegetation records from Europe. Quaternary Science Reviews 29, 2839-2864 (2010).

16. Luetscher, M. et al. North Atlantic storm track changes during the Last Glacial Maximum recorded by Alpine speleothems. Nature Communications 6, 6344 (2015).

17. Genty, D. et al. Precise dating of Dansgaard-Oeschger climate oscillations in western Europe from stalagmite data. Nature 421, 833-837 (2003).

18. Fankhauser, A., McDermott, F. \& Fleitmann, D. Episodic speleothem deposition tracks the terrestrial impact of millennial-scale last glacial climate variability in SW Ireland. Quaternary Science Reviews 152, 104-117 (2016).

19. Andrews, J. E. Palaeoclimatic records from stable isotopes in riverine tufas: Synthesis and review. Earth-Science Reviews 75, 85-104 (2006).

20. Osman, M. B. et al. Globally resolved surface temperatures since the Last Glacial Maximum. Nature 599, 239-244 (2021).

21. Haase, D. et al. Loess in Europe-its spatial distribution based on a European Loess Map, scale 1:2,500,000. Quaternary Science Reviews 26, 1301-1312 (2007).

22. Fenn, K. \& Prud'homme, C. Dust deposits: Loess. in Treatise on Geomorphology (eds. Shroder, J. F., Lancaster, N., Sherman, D. J. \& Baas, A. C. W.) (Academic Press, 2021).

23. Lehmkuhl, F. et al. Loess landscapes of Europe - Mapping, geomorphology, and zonal differentiation. Earth-Science Reviews 103496 (2020) doi:10.1016/j.earscirev.2020.103496.

24. Antoine, P. et al. Rapid and cyclic aeolian deposition during the Last Glacial in European loess: a high-resolution record from Nussloch, Germany. Quaternary Science Reviews 28, 2955-2973 (2009).

25. Moine, 0 . et al. The impact of Last Glacial climate variability in west-European loess revealed by radiocarbon dating of fossil earthworm granules. Proceedings of the National Academy of Sciences of the United States of America 114, 1-6 (2017).

26. Fischer, P. et al. Millennial-scale terrestrial ecosystem responses to Upper Pleistocene climatic changes: 4D-reconstruction of the Schwalbenberg Loess-Palaeosol-Sequence (Middle Rhine Valley, Germany). Catena 196, 104913 (2021). 
27. Rousseau, D.-D. et al. (MIS3 \& 2) millennial oscillations in Greenland dust and Eurasian aeolian records - a paleosol perspective. Quaternary Science Reviews 139, 99-113 (2017).

28. Ložek, V. Molluscs in loess, their paleoecological significance and role in geochronology - Principles and methods. Quaternary International 7-8, 71-79 (1990).

29. Rousseau, D.-D., Puisségur, J. J. \& Lautridou, J. P. Biogeography of the Pleistocene pleniglacial malacofaunas in Europe. Stratigraphic and climatic implications. Palaeogeography, Palaeoclimatology, Palaeoecology 80, 7-23 (1990).

30. Moine, O., Rousseau, D.-D. \& Antoine, P. The impact of Dansgaard-Oeschger cycles on the loessic environment and malacofauna of Nussloch (Germany) during the Upper Weichselian. Quaternary Research 70, 91-104 (2008).

31. Hatté, C. \& Guiot, J. Palaeoprecipitation reconstruction by inverse modelling using the isotopic signal of loess organic matter: Application to the Nußloch loess sequence (Rhine Valley, Germany). Climate Dynamics 25, 315-327 (2005).

32. Hatté, C. et al. $813 \mathrm{C}$ of Loess Organic Matter as a Potential Proxy for Paleoprecipitation. Quaternary Research 55, 33-38 (2001).

33. Zech, R., Gao, L., Tarozo, R. \& Huang, Y. Branched glycerol dialkyl glycerol tetraethers in Pleistocene loess-paleosol sequences: Three case studies. Organic Geochemistry 53, 38-44 (2012).

34. Trigui, Y. et al. First calibration and application of leaf wax n-alkane biomarkers in loess-paleosol sequences and modern plants and soils in Armenia. Geosciences 9, (2019).

35. Zech, M., Rass, S., Buggle, B., Löscher, M. \& Zöller, L. Reconstruction of the late Quaternary paleoenvironments of the Nussloch loess paleosol sequence, Germany, using n-alkane biomarkers. Quaternary Research (United States) 78, 226-235 (2012).

36. Barta, G. Secondary carbonates in loess-paleosoil sequences: a general review. Central European Journal of Geosciences 3, 129-146 (2011).

37. Becze-Deák, J., Langohr, R. \& Verrecchia, E. P. Small scale secondary CaCO3 accumulations in selected sections of the European loess belt. Geoderma 76, 221-252 (1997).

38. Prud'homme, C., Moine, O., Mathieu, J., Saulnier-Copard, S. \& Antoine, P. High-resolution quantification of earthworm calcite granules from western European loess sequences reveals stadial-interstadial climatic variability during the Last Glacial. Boreas 48, 257-268 (2019).

39. Prud'homme, C. et al. Earthworm calcite granules: a new tracker of millennial-timescale environmental changes in Last Glacial loess deposits. Journal of Quaternary Science 30, 529-536 (2015).

40. Canti, M. G. \& G., W. Earthworm Activity and Archaeological Stratigraphy: A Review of Products and Processes. Journal of Archaeological Science 30, 135-148 (2003).

41. Canti, M. G. Origin of calcium carbonate granules found in buried soils and Quaternary deposits. Boreas 27, 275-288 (1998). 
42. Canti, M. G. \& Piearce, T. G. Morphology and dynamics of calcium carbonate granules produced by different earthworm species. Pedobiologia 47, 511-521 (2003).

43. Lee, M. R., Hodson, M. E. \& Langworthy, G. Earthworms produce granules of intricately zoned calcite. Geology 36, 943-946 (2008).

44. Prud'homme, C. et al. Palaeotemperature reconstruction during the Last Glacial from $\delta^{18} \mathrm{O}$ of earthworm calcite granules from Nussloch loess sequence, Germany. Earth and Planetary Science Letters 442, 13-20 (2016).

45. Prud'homme, C. et al. $\delta^{13} \mathrm{C}$ signal of earthworm calcite granules: a new proxy for palaeoprecipitation reconstructions during the Last Glacial in Western Europe. Quaternary Science Reviews 179, 158166 (2018).

46. Schirmer, W. Rhine loess at Schwalbenberg II - MIS 4 and 3. E\&G Quaternary Science Journal 61, 32-47 (2012).

47. Blaauw, M. \& Christeny, J. A. Flexible paleoclimate age-depth models using an autoregressive gamma process. Bayesian Analysis 6, 457-474 (2011).

48. Canti, M. G. Experiments on the origin of $13 \mathrm{C}$ in the calcium carbonate granules produced by the earthworm Lumbricus terrestris. Soil Biology and Biochemistry 41, 2588-2592 (2009).

49. Kohn, M. J. Carbon isotope compositions of terrestrial C3 plants as indicators of (paleo)ecology and (paleo)climate. Proceedings of the National Academy of Sciences 107, 19691-19695 (2010).

50. Rey, K. et al. Late Miocene climatic and environmental variations in northern Greece inferred from stable isotope compositions (delta 0-18, delta C-13) of equid teeth apatite. Palaeogeography Palaeoclimatology Palaeoecology 388, 48-57 (2013).

51. Hare, V. J., Loftus, E., Jeffrey, A. \& Ramsey, C. B. Atmospheric CO2 effect on stable carbon isotope composition of terrestrial fossil archives. Nature Communications 9, (2018).

52. Versteegh, E. A. A., Black, S., Canti, M. G. \& Hodson, M. E. Earthworm-produced calcite granules: A new terrestrial palaeothermometer? Geochimica et Cosmochimica Acta 123, 351-357 (2013).

53. Łacka, B., Łanczont, M. \& Madeyska, T. Oxygen and carbon stable isotope composition of authigenic carbonates in loess sequences from the Carpathian margin and Podolia, as a palaeoclimatic record. Quaternary International 198, 136-151 (2009).

54. Dansgaard, W. Stable isotopes in precipitation. Tellus 16, 436-468 (1964).

55. Rozanski, K. Deuterium and oxygen-18 in European Groundwaters-Links to Atmospheric Circulation in the Pst. Chemical Geology vol. 52 349-363 (1985).

56. Lambeck, K. \& Chappell, J. Sea Level Change Through the Last Glacial Cycle. Science 292, 679-686 (2001).

57. Toucanne, S. et al. Timing of massive "Fleuve Manche" discharges over the last 350 kyr: insights into the European ice-sheet oscillations and the European drainage network from MIS 10 to 2. Quaternary Science Reviews 28, 1238-1256 (2009). 
58. Schrag, D. P. et al. The oxygen isotopic composition of seawater during the Last Glacial Maximum. Quaternary Science Reviews 21, 331-342 (2002).

59. Shackleton, N. J. The 100,000-Year Ice-Age Cycle Identified and Found to Lag Temperature, Carbon Dioxide, and Orbital Eccentricity. Science 289, 1897-1902 (2000).

60. Zhang, T., Osterkamp, T. E. \& Stamnes, K. Effects of Climate on the Active Layer and Permafrost on the North Slope of Alaska, U.S.A. Permafrost and Periglacial Processes 8, 45-67 (1997).

61. Christiansen, H. H. et al. The thermal state of permafrost in the nordic area during the international polar year 2007-2009. Permafrost and Periglacial Processes 21, 156-181 (2010).

62. Dee, D. P. et al. The ERA-Interim reanalysis: configuration and performance of the data assimilation system. Quarterly Journal of the Royal Meteorological Society 137, 553-597 (2011).

63. Vinnepand, M. et al. Combining Inorganic and Organic Carbon Stable Isotope Signatures in the Schwalbenberg Loess-Palaeosol-Sequence Near Remagen (Middle Rhine Valley, Germany). Frontiers in Earth Science 8, (2020).

64. Rousseau, D.-D. et al. Link between European and North Atlantic abrupt climate changes over the last glaciation. Geophysical Research Letters 34, L22713 (2007).

65. Frechen, M. \& Schirmer, W. Luminescence Chronology of the Schwalbenberg II Loess in the Middle Rhine Valley. Eiszeitalter und Gegenwart 60, 78-89 (2011).

66. Moine, O., Rousseau, D.-D. \& Antoine, P. Terrestrial molluscan records of Weichselian Lower to Middle Pleniglacial climatic changes from the Nussloch loess series (Rhine Valley, Germany): The impact of local factors. Boreas 34, 363-380 (2005).

67. Hatté, C., Rousseau, D.-D. \& Guiot, J. Climate reconstruction from pollen and $\delta^{13} \mathrm{C}$ using inverse vegetation modeling. Implication for past and future climates. Climate of the Past Discussions $\mathbf{5}$, 73-98 (2009).

68. Ampel, L. et al. Modest summer temperature variability during DO cycles in western Europe. Quaternary Science Reviews 29, 1322-1327 (2010).

69. Rousseau, D.-D. Climatic Transfer-Function From Quaternary Mollusks in European Loess Deposits. Quaternary Research 36, 195-209 (1991).

70. Moine, O., Rousseau, D.-D., Jolly, D. \& Vianey-Liaud, M. Paleoclimatic Reconstruction Using Mutual Climatic Range on Terrestrial Mollusks. Quaternary Research 57, 162-172 (2002).

71. Ponel, P. Rissian, Eemian and Würmian Coleoptera assemblages from La Grande Pile (Vosges, France). Palaeogeography, Palaeoclimatology, Palaeoecology 114, 1-41 (1995).

72. Zamanian, K., Lechler, A. R., Schauer, A. J., Kuzyakov, Y. \& Huntington, K. W. The $\delta 13 C, \delta 180$ and $\Delta 47$ records in biogenic, pedogenic and geogenic carbonate types from paleosol-loess sequence and their paleoenvironmental meaning. Quaternary Research (United States) 101, 256-272 (2021).

73. Hatté, C., Rousseau, D.-D. \& Guiot, J. Climate reconstruction from pollen and delta $\delta^{13} \mathrm{C}$ records using inverse vegetation modeling - Implication for past and future climates (vol 5, pg 147, 2009). Climate of the Past 6, 83-84 (2010). 
74. Kindler, P. et al. Temperature reconstruction from 10 to $120 \mathrm{kyr}$ b2k from the NGRIP ice core. Climate of the Past 10, 887-902 (2014).

75. Újvári, G. et al. Coupled European and Greenland last glacial dust activity driven by North Atlantic climate. Proceedings of the National Academy of Sciences 201712651 (2017) doi:10.1073/pnas.1712651114.

76. Stevens, T. et al. Abrupt last glacial dust fall over southeast England associated with dynamics of the British-Irish ice sheet. Quaternary Science Reviews 250, (2020).

77. Moine, O. Weichselian Upper Pleniglacial environmental variability in north-western Europe reconstructed from terrestrial mollusc faunas and its relationship with the presence/absence of human settlements. Quaternary Internationa/ 337, 90-113 (2014).

78. Ampel, L., Wohlfarth, B., Risberg, J. \& Veres, D. Paleolimnological response to millennial and centennial scale climate variability during MIS 3 and 2 as suggested by the diatom record in Les Echets, France. Quaternary Science Reviews 27, 1493-1504 (2008).

79. Hughes, A. L. C., Gyllencreutz, R., Lohne, Ø. S., Mangerud, J. \& Svendsen, J. I. The last Eurasian ice sheets - a chronological database and time-slice reconstruction, DATED-1. Boreas 45, 1-45 (2016).

80. Patton, H., Hubbard, A., Andreassen, K., Winsborrow, M. \& Stroeven, A. P. The build-up, configuration, and dynamical sensitivity of the Eurasian ice-sheet complex to Late Weichselian climatic and oceanic forcing. Quaternary Science Reviews 153, 97-121 (2016).

81. Toucanne, S. et al. The North Atlantic Glacial Eastern Boundary Current as a Key Driver for Ice-Sheet -AMOC Interactions and Climate Instability. Paleoceanography and Paleoclimatology 36, e2020PA004068 (2021).

82. Spötl, C., Koltai, G., Jarosch, A. H. \& Cheng, H. Increased autumn and winter precipitation during the Last Glacial Maximum in the European Alps. Nature Communications 12, (2021).

83. Stokes, C. R., Tarasov, L. \& Dyke, A. S. Dynamics of the North American Ice Sheet Complex during its inception and build-up to the Last Glacial Maximum. Quaternary Science Reviews 50, 86-104 (2012).

84. Serreze, M. C., Carse, F., Barry, R. G. \& Rogers, J. C. Icelandic Low Cyclone Activity: Climatological Features, Linkages with the NAO, and Relationships with Recent Changes in the Northern Hemisphere Circulation.

85. App, V., Auffermann, B., Hahn, J., Pasda, C. \& Stephan, E. Die altsteinzeitliche Fundstelle auf dem Schwalbenberg bei Remagen. Berichte zur Archäologie an Mittelrhein und Mosel, 4, 11-136 (1995).

86. Tisnérat-Laborde, N., Poupeau, J., ... J. T.- \& 2001, undefined. Development of a semi-automated system for routine preparation of carbonate samples. cambridge.org 43, 299-304 (2001).

87. Cottereau, E. et al. Artemis, the new 14C AMS at LMC14 in Saclay, France. Radiocarbon 49, 291-299 (2007).

88. Ruff, M. et al. A gas ion source for radiocarbon measurements at $200 \mathrm{kV}$. cambridge.org 49, 307-314 (2007). 
89. Tisnérat-Laborde, N. et al. ECHoMICADAS: A new compact AMS system to measuring 14C for Environment, Climate and Human Sciences. in International Radiocarbon Conference, Dakar, Senegal 16-20 (2015).

90. Synal, H., Stocker, M. \& Suter, M. MICADAS: a new compact radiocarbon AMS system. Nuclear Instruments and Methods in Physics Research Section B: Beam Interactions with Materials and Atoms 259, 7-13 (2007).

91. Reimer, P. J., Brown, T. A. \& Reimer, R. W. Discussion: Reporting and calibration of post-bomb $14 \mathrm{C}$ data. Radiocarbon 46, 1299-1304 (2004).

92. Stuiver, M. \& Polach A. Henry. Discussion Reporting of 14C Data. Radiocarbon 19, 355-363 (1977).

93. Millard, A. R. Conventions for Reporting Radiocarbon Determinations. Radiocarbon 56, 555-559 (2014).

94. Reimer, P. J. et al. The IntCal20 Northern Hemisphere Radiocarbon Age Calibration Curve (0-55 cal kBP). Radiocarbon 62, 725-757 (2020).

95. Pongratz, J., Reick, C. H., Raddatz, T. \& Claussen, M. Effects of anthropogenic land cover change on the carbon cycle of the last millennium. Global Biogeochemical Cycles 23, (2009).

96. Hargreaves, J. C., Annan, J. D., Ohgaito, R., Paul, A. \& Abe-Ouchi, A. Skill and reliability of climate model ensembles at the Last Glacial Maximum and mid-Holocene. Climate of the Past 9, 811-823 (2013).

97. Berger, A. \& Loutre, M. F. Insolation values for the climate of the last 10 million years. Quaternary Science Reviews 10, 297-317 (1991).

\section{Table}

Table $1 \mathrm{xlsx}$ is available in the Supplemental Files section.

\section{Figures}




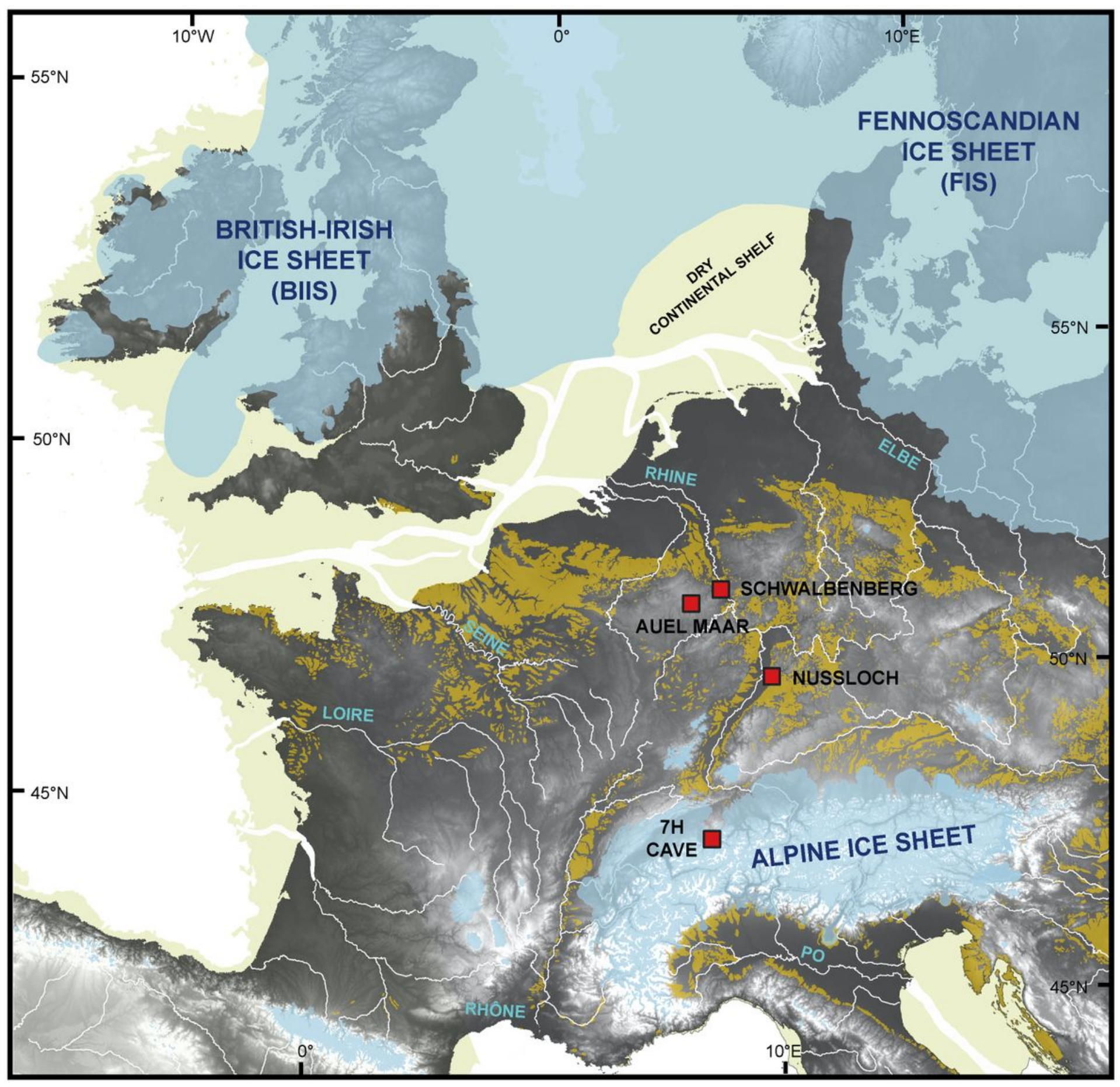

Figure 1

DEM-based map showing the Paleogeography of Western and Central Europe during the Last Glacial Maximum (LGM $\sim 21 \mathrm{ka})$. The distance between Schwalbenberg $\left(50.56^{\circ} \mathrm{N} ; 7.24^{\circ} \mathrm{E}\right)$ and Nussloch $\left(49.18^{\circ} \mathrm{N} ; 8.70^{\circ} \mathrm{E}\right)$ loess sites is $\sim 180 \mathrm{~km}$. Yellow patches represented areas of loess and loess derivates ${ }^{21,23}$. Beige-colored areas represent the dry continental shelves ${ }^{23}$. The DEM is based on combined DEMs ${ }^{21}$ of the GLOBE Project ( $1 \mathrm{~km}$ resolution DEM). 


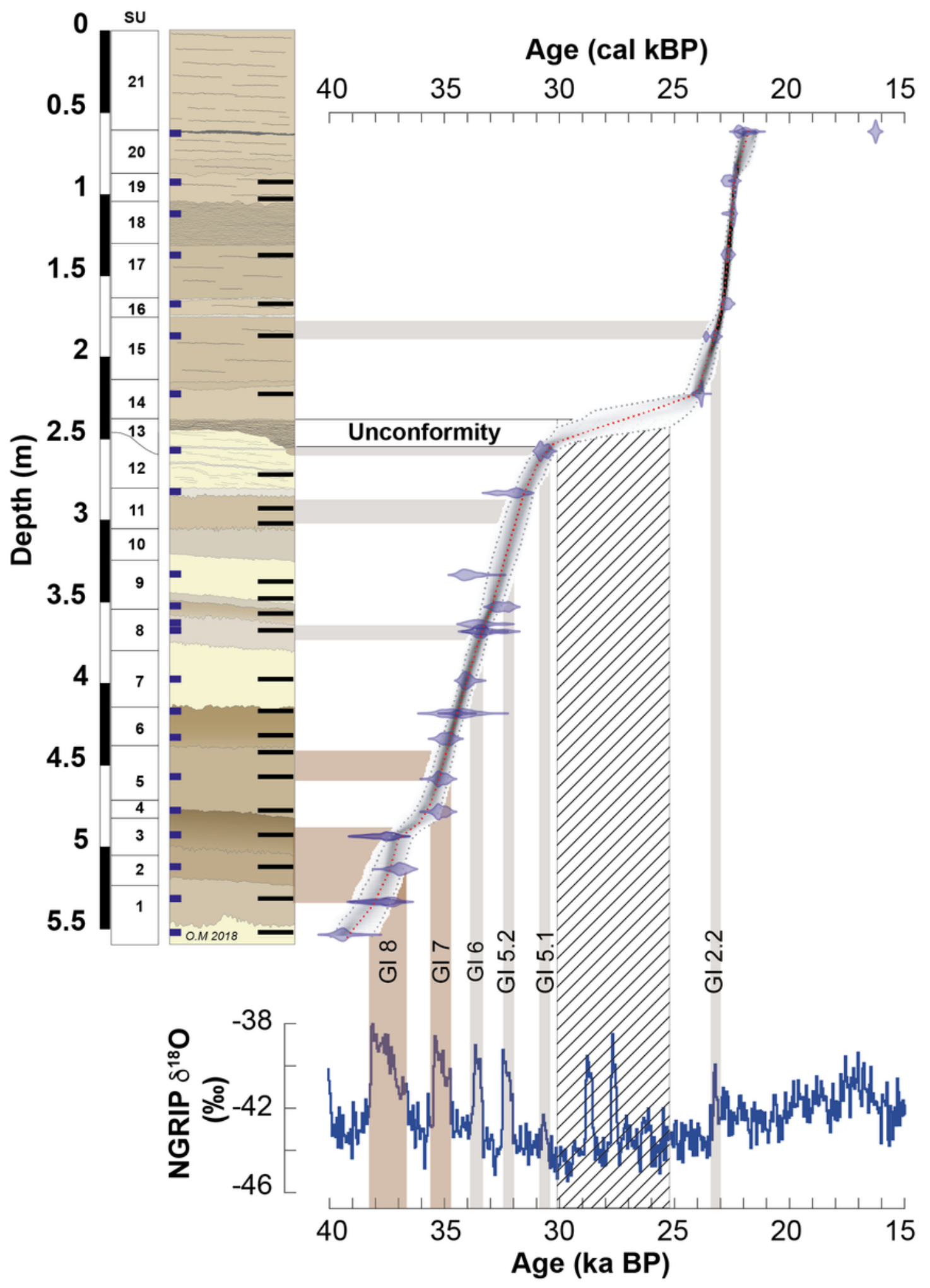

Figure 2

Age model of the Schwalbenberg loess profile RP1 - Age model is based on Bayesian modelling using the software Bacon ${ }^{47}$ with 23 radiocarbon ages from 28 horizons calibrated with IntCal20. The chronology of the profile is correlated with the $\delta^{18} \mathrm{O}$ of NGRIP3. Originally given in b2K ages, their chronological scale has been shifted by 50 years to allow for direct comparisons with the radiocarbon 
dating given in years BP (before 1950). SU - sediment units. Developed palaeosols are representing in brown and tundra gley horizons in grey.

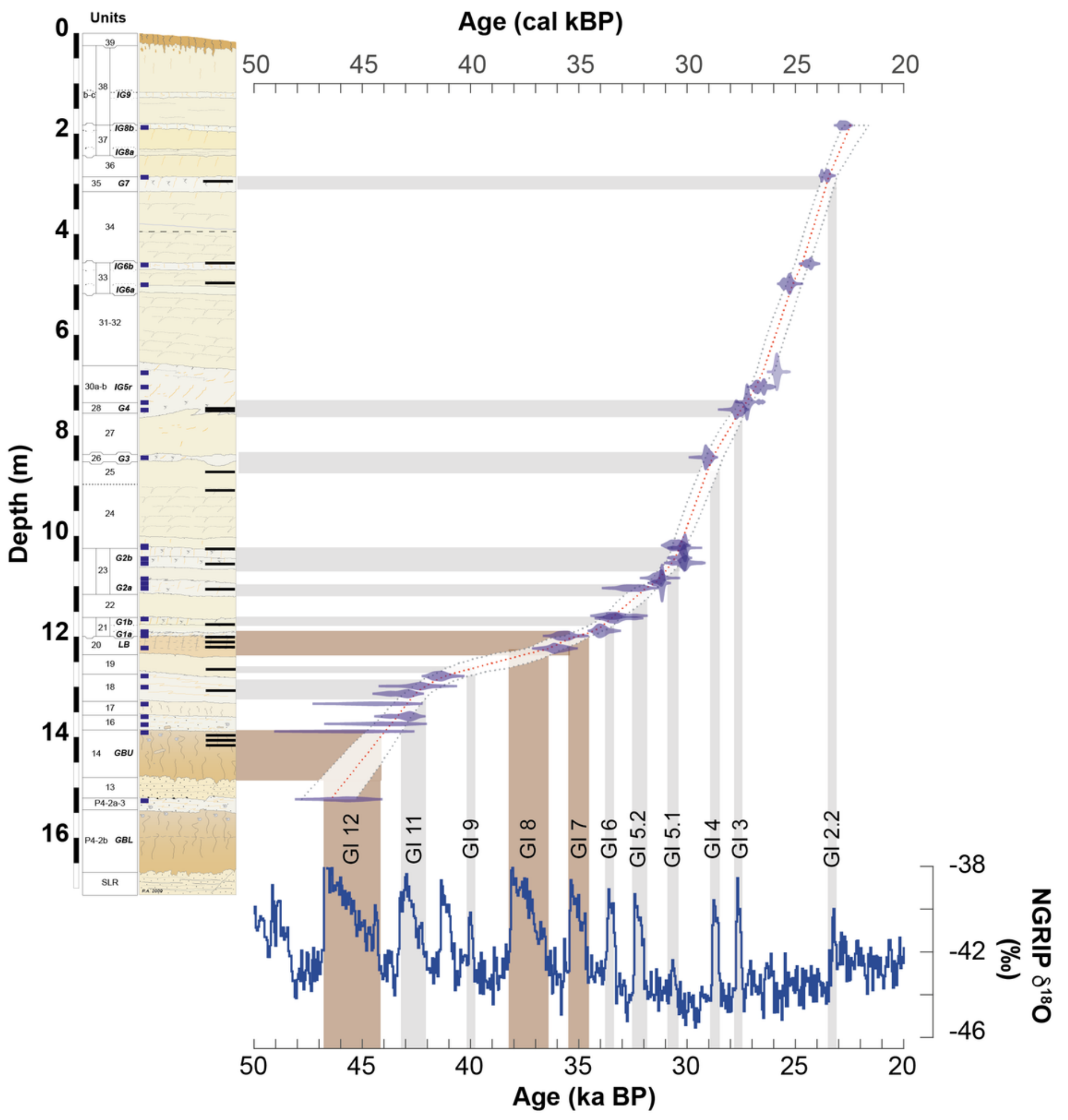

Figure 3

Age model of the Nussloch loess profile P8 - Age model is based on Bayesian modelling using the software Bacon ${ }^{47}$ with 29 radiocarbon ages ${ }^{25}$ calibrated with IntCal20. The chronology of the profile is 
correlated with the $\delta^{18} \mathrm{O}$ of $\mathrm{NGRIP}^{3}$. Originally given in b2K ages, their chronological scale has been shifted by 50 years to allow for direct comparisons with the radiocarbon dating given in years BP (before 1950). Developed palaeosols are representing in brown and tundra gley horizons in grey.

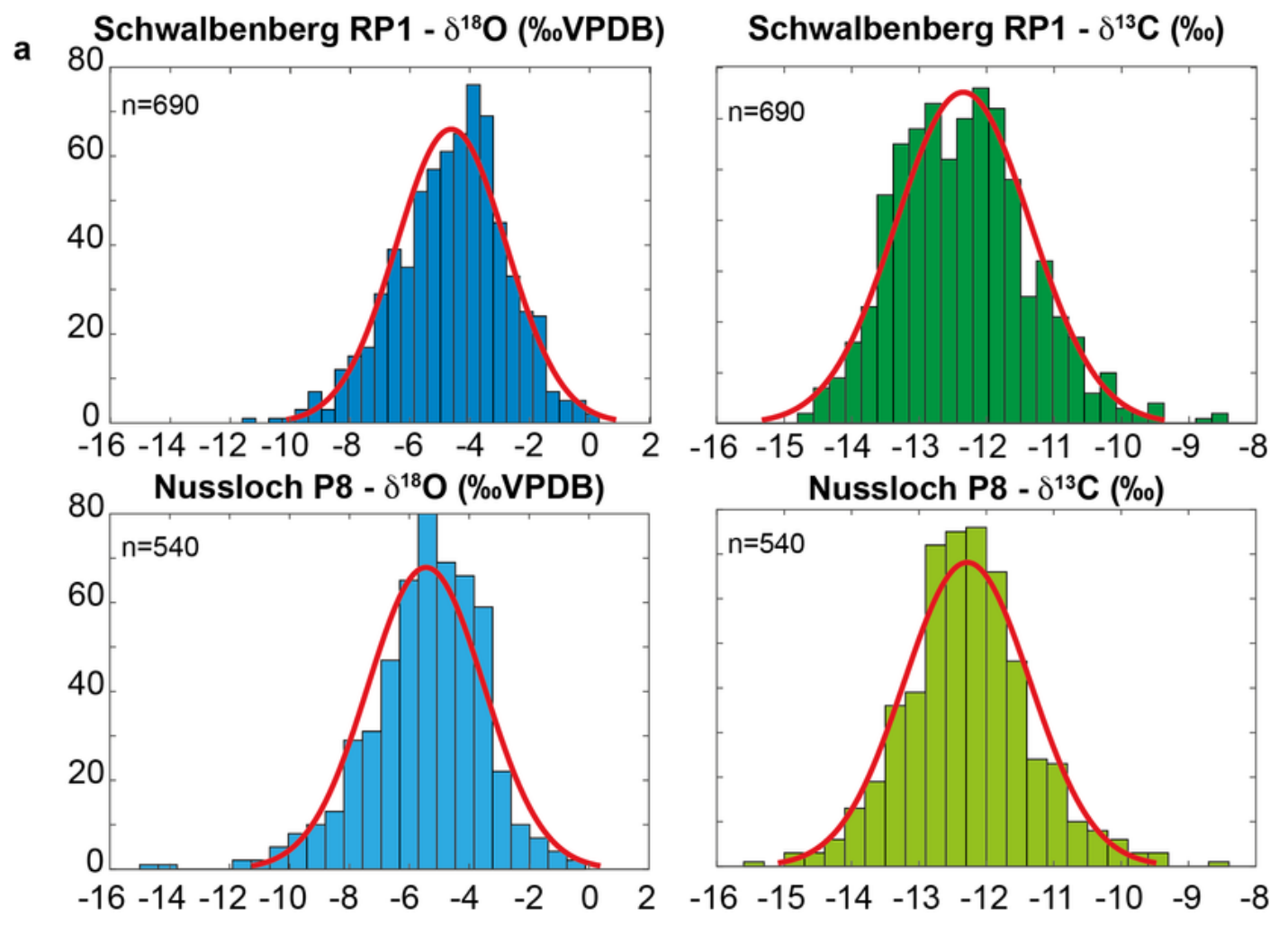

b

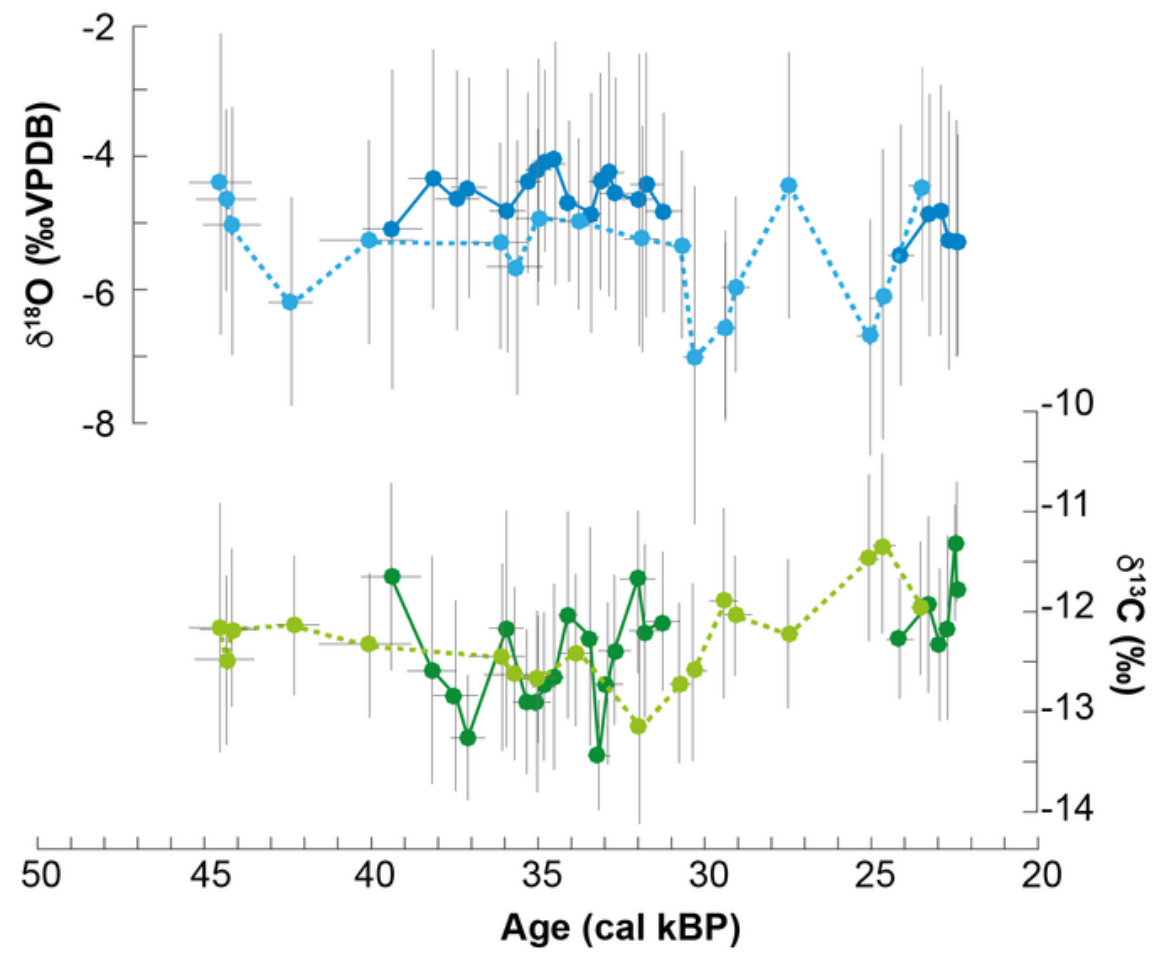

Figure 4 
Stable isotope composition of ECGs from Nussloch and Schwalbenberg a) Histogram of oxygen and carbon compositions for both sequences; b) Nussloch (light-coloured dotted lines) and Schwalbenberg (dark-coloured plain lines) $\delta^{13} \mathrm{C}$ and $\delta^{18} \mathrm{O}$ curves versus chronology based on radiocarbon dating calibrated with IntCal20.

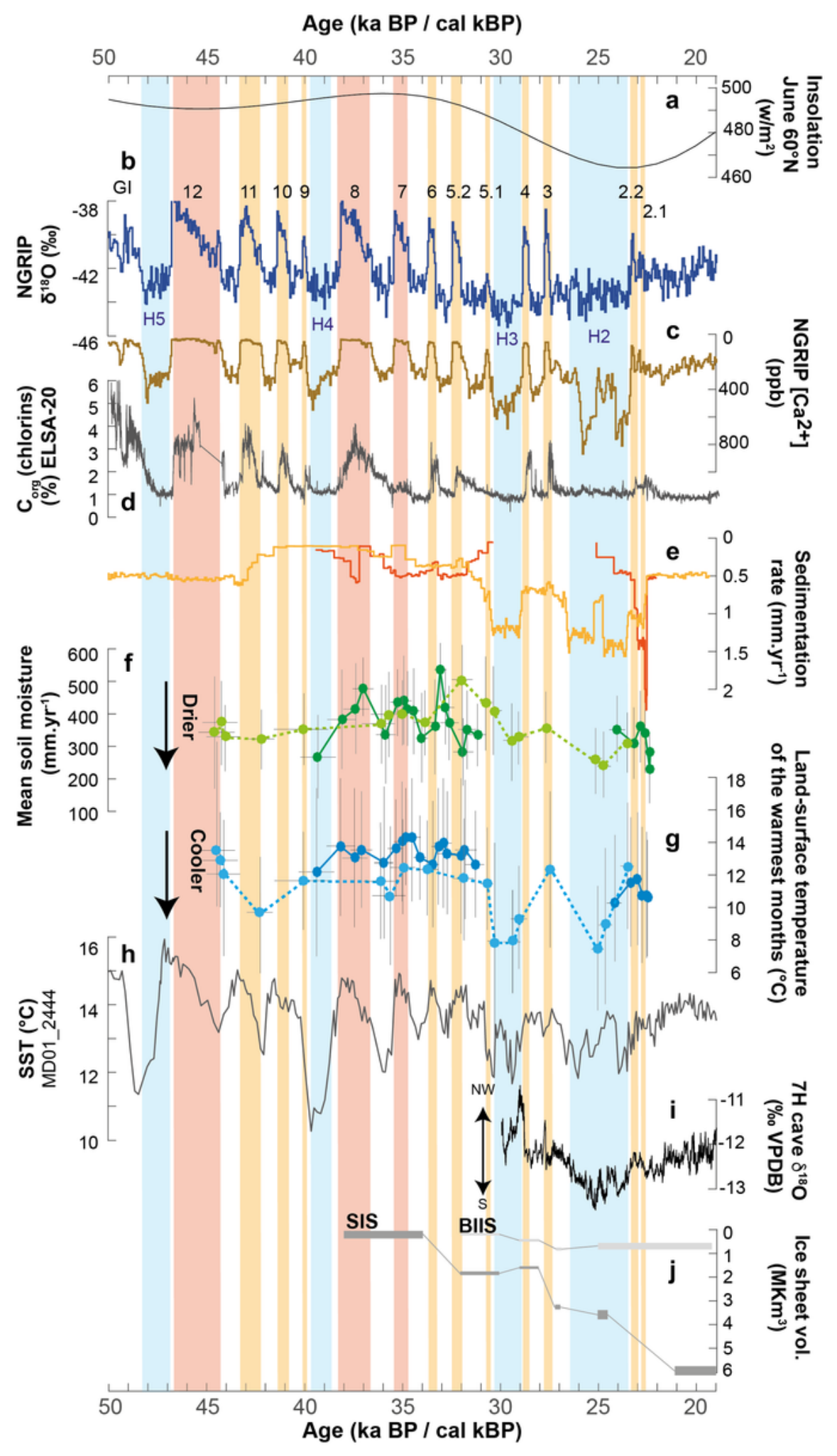

Figure 5 


\section{Climate reconstructions and dust variation in terrestrial and glacial environments in across the North}

Atlantic Region - a) June insolation at $60^{\circ} \mathrm{N}^{97}$; b) $\delta^{18} \mathrm{O}$ ratio and c) $\mathrm{Ca}^{+}$concentration of NGRIP Greenland ice core ${ }^{3}$. Originally given in b2K ages, their chronological scale has been shifted by 50 years to allow for direct comparisons with the radiocarbon dating given in years BP (before 1950). d) ELSA20$\mathrm{C}_{\text {org }}$ (chlorins) ${ }^{12}$ referred to cal BP; e) Sedimentation rate from Nussloch and Schwalbenberg profiles, radiocarbon dating calibrated with IntCal20; f) Mean annual precipitation reconstruction based on the $\delta^{13} \mathrm{C}$ values of ECG for both loess profiles, radiocarbon dating calibrated with IntCal20; g) Land-surface temperature of the warmest month estimated from the $\delta^{18} \mathrm{O}$ values of ECG for both loess profiles, radiocarbon dating calibrated with IntCal20; h) Iberian margin sea surface temperature (SST, MD01 $2444)^{6}$, radiocarbon dating calibrated with IntCal13; i) The $\delta^{18} \mathrm{O}$ of meteoric water from the Alps based on the $\delta^{18} \mathrm{O}$ of the Sieben Hengste Cave $(7 \mathrm{H})$ speleothem ${ }^{16}, \mathrm{U}$-Th dating in ka BP; j) Ice sheet area and volume reconstruction ${ }^{80}$. $\mathrm{H} 2-\mathrm{H} 5$ - Heinrich stadials (in blue). Palaeosols formed during long Greenland Interstadials are highlighted in reddish (GI 12,8,7); and tundra gleys developed during short Greenland Interstadials are in yellow $(\mathrm{GI} 11,10,9,6,5.2,5.1,4,3,2.2,2.1)^{27}$. 


\section{Nussloch}

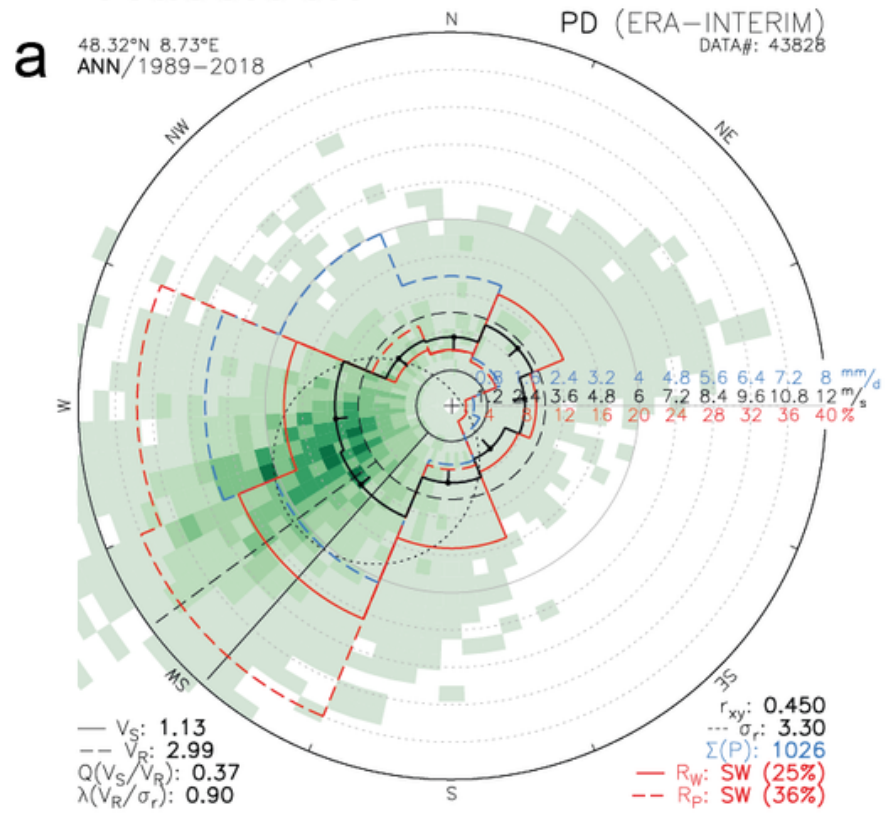

\section{Schwalbenberg}

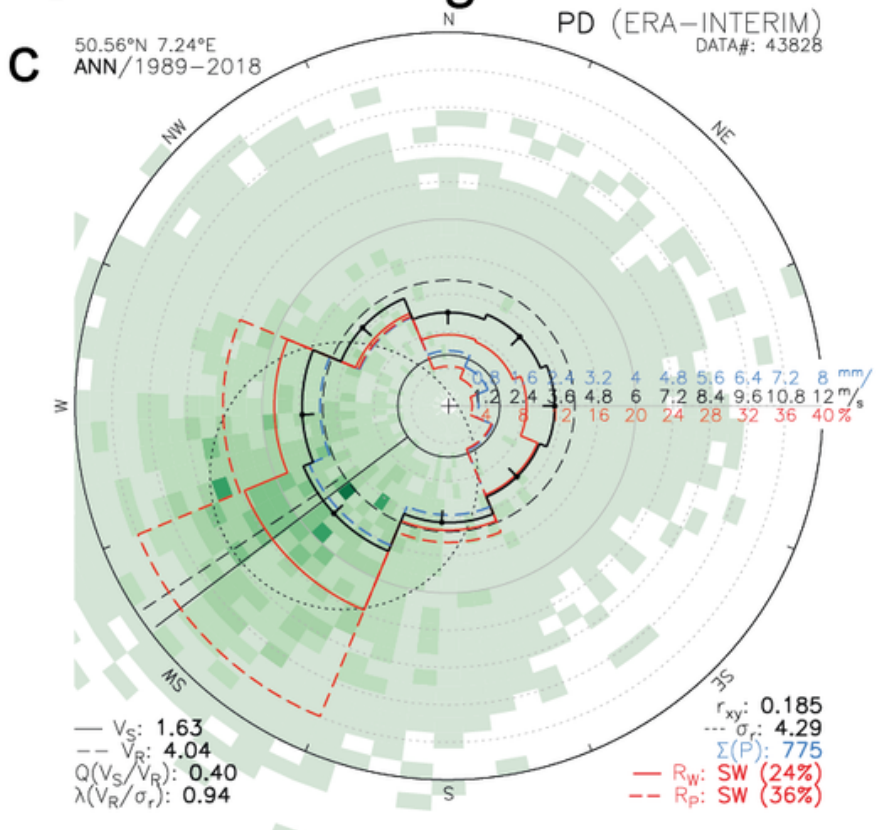

○

0.3

0.4

\section{Nussloch}

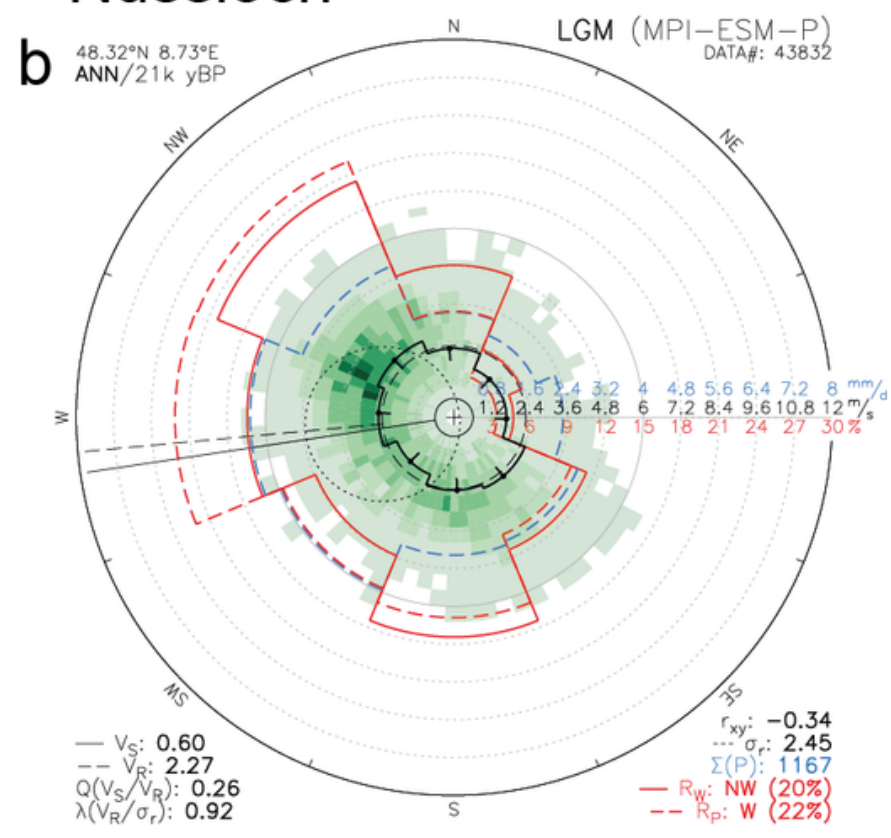

\section{Schwalbenberg}

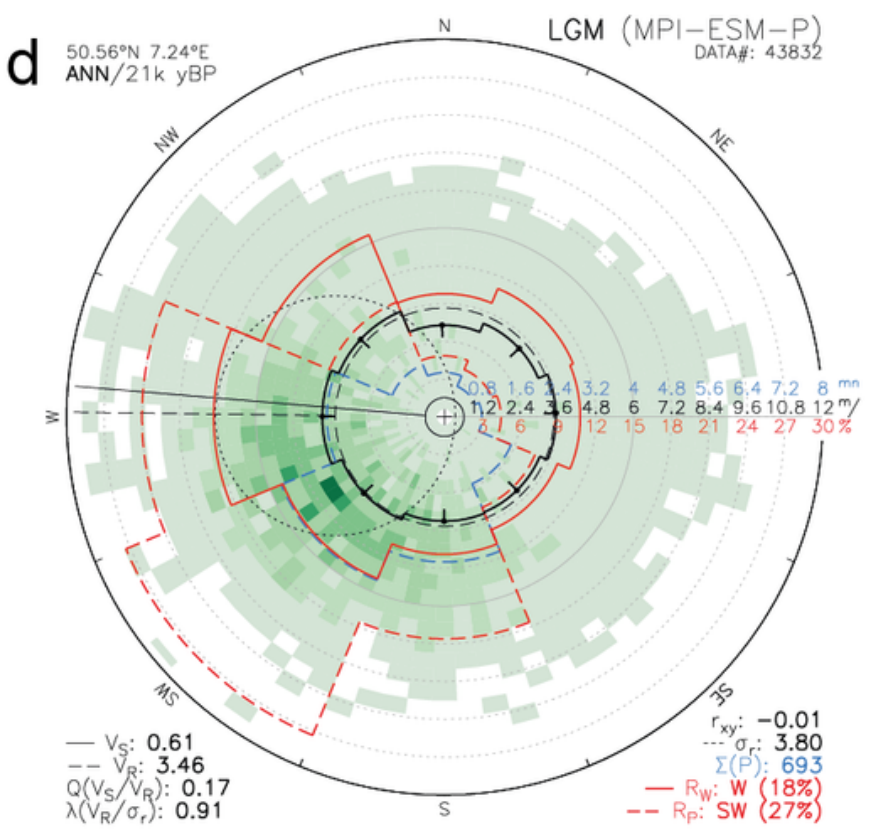

0.5

0.6

0.7

0.8

\section{Figure 6}

Annual wind regime and precipitation statistics obtained for present day and LGM conditions at Nussloch site $(a, b)$ and Schwalbenberg $(c, d)$. Shaded area presents the average precipitation flux at given wind direction/strength (percent of total). Sector line plots show wind speed (black), wind occurrence (red solid), precipitation rate (blue dashed) and total precipitation (red dashed, normalized) distribution about rhumbs. Thin solid/long-dashed line circles visualize the scalar/absolute winds and their directions, 
respectively; thin-dashed circle shows wind vector. SD. Note that wind direction is meteorological (from where wind blows). Further statistics tabled: $V_{S}$ and $V_{R}-$ absolute and scalar wind speed $[\mathrm{m} / \mathrm{s}], \mathrm{R}_{\mathrm{w}}$ and $\mathrm{R}_{\mathrm{p}}$

- rhumbs of maximum wind and precipitation occurrence [percent], $Q$ - wind steadiness $\left(V_{S} / V_{R}\right.$ ratio), $r_{x y}$ - wind zonal and meridional components correlation, $\sigma_{r}$ - wind vector SD $[\mathrm{m} / \mathrm{s}], \lambda$ - wind absolute speed to $S D$ ratio, $\Sigma(P)$ : total annual precipitation $[\mathrm{mm}]$.

\section{Supplementary Files}

This is a list of supplementary files associated with this preprint. Click to download.

- Tables1SM14CageV2.xIsx

- FigS1RP1d180d13C.png

- FigS2Nusslochd180D13C.png

- FigS3windprecipRemagen.png

- FigS4windprecipNuss.png

- SupplementaryMaterialsRemagenNusslochComEE.docx

- Table1RP1NUSSclimatereconstrution.xlsx 